The Psychology of High Abilities 
Also by Michael J. A. Howe

Understanding School Learning

Learning in Infants and Young Children

Adult Learning

Learning from Television

Introduction to Human Memory

A Teachers' Guide to the Psychology of Learning

Television and Children

The Psychology of Human Learning

Introduction to the Psychology of Memory

Fragments of Genius: the Strange Feats of Idiots Savants

Encouraging the Development of Exceptional Skills and Talents

Sense and Nonsense about Hothouse Children

Give Your Child a Better Start (with Harriet Griffey)

Principles of Human Abilities and Learning

IQ in Question: The Truth about Intelligence 


\section{The Psychology of High Abilities}

Michael J. A. Howe 


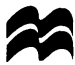

(C) Michael J. A. Howe 1999

All rights reserved. No reproduction, copy or transmission of this publication may be made without written permission.

No paragraph of this publication may be reproduced, copied or transmitted save with written permission or in accordance with the provisions of the Copyright, Designs and Patents Act 1988, or under the terms of any licence permitting limited copying issued by the Copyright Licensing Agency, 90 Tottenham Court Road, London W1P 0LP.

Any person who does any unauthorised act in relation to this publication may be liable to criminal prosecution and civil claims for damages.

The author has asserted his right to be identified as the author of this work in accordance with the Copyright, Designs and Patents Act 1988.

First published 1999 by MACMILLAN PRESS LTD

Houndmills, Basingstoke, Hampshire RG21 6XS and London

Companies and representatives throughout the world

ISBN 978-0-333-75097-1

DOI $10.1007 / 978-1-349-27647-9$

ISBN 978-1-349-27647-9 (eBook)

A catalogue record for this book is available

from the British Library.

This book is printed on paper suitable for recycling and made from fully managed and sustained forest sources.

$\begin{array}{llllllllll}10 & 9 & 8 & 7 & 6 & 5 & 4 & 3 & 2 & 1\end{array}$

$\begin{array}{llllllllll}08 & 07 & 06 & 05 & 04 & 03 & 02 & 01 & 00 & 99\end{array}$

Editing and origination by Aardvark Editorial, Mendham, Suffolk 


\section{Contents}

Preface

1 Some influences on abilities 1

Training and hard work $\quad 2$

A good start 6

Innate gifts and talents $\quad 11$

Some tentative conclusions $\quad 16$

The book's contents $\quad 17$

2 Family backgrounds $\quad 19$

The influence of the family 19

How families influence children $\quad 22$

Mechanisms of family influence: the Chicago studies 29

Distinguishing between environment and experience 32

Sex and gender differences 33

Patterns of interaction in the earliest years 35

How crucial are the earliest years of life? 37

The years following infancy: Feuerstein's insights $\quad 41$

Problems of family life $\quad 47$

The different influences of family and school 49

3 Accelerating the acquisition of children's abilities 52

Gesell's studies of accelerated learning 52

A deprivation experiment $\quad 54$

Accelerating physical skills $\quad 56$

Accelerating the acquisition of language 57

Early reading $\quad 65$

Accelerating progress at musical skills $\quad 72$

Extraordinary skills in ordinary adults $\quad 75$

Unusual perceptual capabilities $\quad 79$

Some conclusions $\quad 80$

Possible negative consequences of accelerated learning 81 
4 Child prodigies

Two prodigies: 1. George Bidder

83

2. Norbert Wiener

87

To be a genius, is it necessary to have been a child prodigy?

How do families contribute to childhood precocity?

What special difficulties and problems do child prodigies experience?

What happens to child prodigies when they become adults?

At how early a stage do prodigies begin to display their exceptionality?

Do parental efforts to accelerate a child's early progress sometimes fail entirely?

\section{Geniuses}

The impossibility of defining genius

Varieties of genius

126

Qualities geniuses share

The necessity for training

Creative activities

Inventions from scratch?

Breadth of interests

Conclusion

6 Intelligence and high abilities

Intelligence tests as predictors of accomplishments

Intelligence tests and superior abilities

Intelligence as an explanation

A general factor

7 Innate talents: reality or myth?

The talent account and its implications

An important distinction

Innate differences and their possible effects on abilities

The roles of genetic materials

Can genetic effects be measured? 
Conclusion: alternative causes of the phenomena attributed to innate talents

8 Helping young people to learn 167

Impediments to parental encouragement 168

Practicalities of helping young children to learn: some parents' approaches 171

Conclusion: chance and fortune in human life $\quad 181$

$\begin{array}{ll}\text { References } & 183\end{array}$

$\begin{array}{ll}\text { Index } & 194\end{array}$ 


\section{Preface}

High abilities are a vital human resource, and the aim of The Psychology of High Abilities is to explain how, when and why people acquire them, and illuminate ways of making it possible for larger numbers of young people to extend their capabilities. It was originally intended that The Psychology of High Abilities would be a shorter and more up-to-date version of an earlier book, The Origins of Exceptional Abilities, which was first published in 1990. However, it soon became apparent that the changes would need to be far more substantial than I had anticipated, and less than half of The Psychology of High Abilities is directly based on the earlier book.

Because high abilities are so valuable, there is much to be gained from striving to understand their causes. It is not always easy to know for certain why one individual rather than another has gained impressive capabilities. Explaining that can be so difficult, and there is always a temptation to assume that the origins of exceptional abilities are a complete mystery. There is also a tendency for people to assume that special genes or special innate gifts must be at the root of unusual capabilities, without even stopping to establish whether or not there is a scientific justification for that assumption. Simply because they cannot think of alternative explanations, some people leap to the conclusion that innate talents must be the cause. In reality, as soon as one seriously looks for them, a substantial number of other influences that contribute to individual variability in human abilities become evident.

We cannot manufacture geniuses, but we can take steps that substantially increase the likelihood of young people acquiring high degrees of competence in various fields of expertise, and enjoying lives that are productive and successful as well as fulfilling. And although our knowledge of the causes of the most exceptional abilities is certainly incomplete, we do know 
sufficient to make it possible to design and implement educational policies that could lead to substantial increase in the proportion of young people who master the difficult skills that society rightly values.

My thanks to the numerous individuals who have helped to make this book possible. They include John Sloboda, Jane Davidson, Steve Ceci, John Radford, Joan Freeman and Anders Ericsson, as well as a number of other friends and colleagues. At Macmillans, Frances Arnold has been especially helpful and encouraging. Thanks also to Sylvia, for her constant support. 